\title{
Professor Jaroslav Koutecký In Memoriam
}

\author{
It is not only the talent \\ that makes a great scientist, \\ it is the character. \\ Albert Einstein, 1928
}

The participants of ISSPIC 14 paid tribute to the memory of Professor RNDr. Jaroslav Koutecký, Dr.Sc., Dr.h.c.(mult.), Emeritus Professor at the Free University of Berlin, an outstanding scientist, a remarkable person and a dear friend to many of us. On the scientific level, Jaroslav Koutecký made seminal contributions to theoretical molecular sciences in general, and to cluster science in particular. On the personal level, I was privileged to consider myself as a part of Jaroslav Koutecký's scientific family and circle of friends, since our paths first crossed in August 1964 in Istanbul at the International Summer School in Modern Quantum Chemistry. As a young scientist, I was tremendously impressed with Jaroslav, then already a world leader in the field of quantum chemistry. This was the beginning of a lifelong friendship, and I am privileged that I had Jaroslav as a friend, with whom I shared so many scientific interests and common cultural and moral values.

The most important and significant scientific contributions of Professor Jaroslav Koutecký were internationally recognized at an early stage of his scientific work. The photograph shows Jaroslav Koutecký in 1973, at the age of 51 (sitting second from the right), attending a meeting of the International Academy of Quantum Molecular Sciences. The Academy, established by De Broglie, constitutes a most distinguished scientific body to whose group Professor Koutecký belonged as a member. In this photograph we can see several great figures of science, among them K. Fukui, John Pople, Per-Olov Lowdin, Martin Karplus, Bright Wilson, Robert Milliken, Bernard Pullman, Alberte Pullman, John Slater John Van Vleck and Robert Parr. Four of these distinguished scientists were Nobel Prize laureates, so this was the reference company of Jaroslav Koutecký.

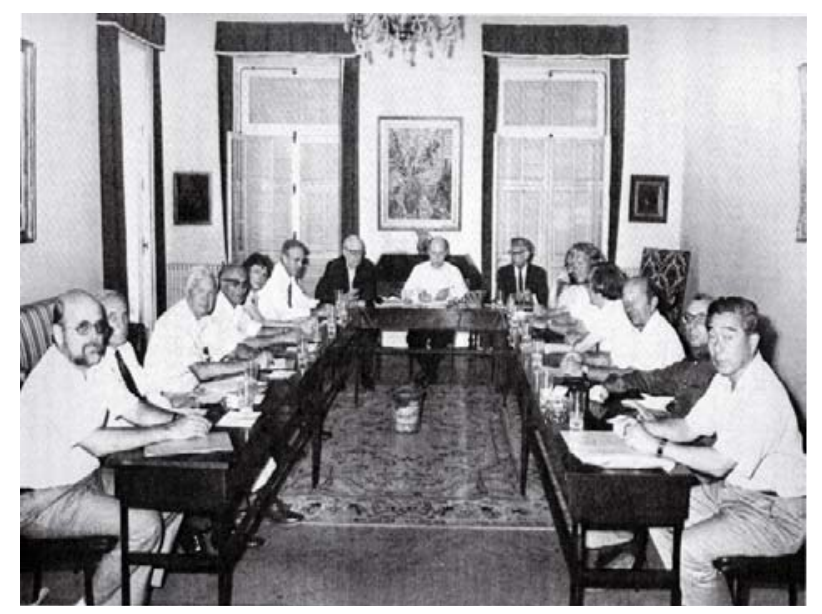

The 1973 session of the International Academy of Quantum Molecular Sciences in Menton, France. Jaroslav Koutecký sits second from the right. Members of the Academy (from left to right) R.G. Parr, J.H. van Vleck, J.C. Slater, B. Pullman, A. Pullman, E. Scrocco, R.S. Mulliken, R. Daudel, E.B. Wilson, M. Karplus. P-O Lowdin, J.A. Pople, R. Pauncz, J. Koutecký, and F. Kukui. 


\section{A. THE EARLY DAYS}

1922 BORN IN KROMERITZ, CZECHOSLOVAKIA

1941 GRADUATED FROM HIGH SCHOOL

1941-44 LABORATORY ASSISTANT, BATA WORKS, ZLIN

1945-47 STUDYING THEORETICAL PHYSICS, FACULTY OF NATURAL SCIENCES, CHARLES UNIVERSITY, PRAGUE

1948 SERVING 6 MONTHS IN A LABOR CAMP

1951 RNDr DEGREE

1952-57 INSTITUTE OF PHYSICAL CHEMISTRY, THE CZECHOSLOVAK ACADEMY OF SCIENCES THEORETICAL POLAROGRAPHY (WITH R. BRDIČKA)

- SURFACE ABSORPTION AND HETEROGENEOUS CATALYSIS

- SURFACE STATES AND DANGLING BONDS, THE CZECHOSLOVAK ACADEMY OF SCIENCES

- CHEMISORPTION

- AD ATOMS ON METAL AND SEMICONDUCTOR SURFACES

\section{B. IMPORTANT CONTRIBUTIONS TO THEORETICAL CHEMISTRY}

1955-67 INSTITUTE OF PHYSICAL CHEMISTRY,

THE CZECHOSLOVAK ACADEMY OF SCIENCES (CAS)

- $\pi$ ELECTRON SYSTEMS (HUCKEL AND PPP) STABILITY, ELECTRONIC SPECTRA, CHEMICAL REACTIVITY

- KOUTECKÝ STATES: LOW LYING VALENCE EXCITATIONS / CAROTENE BASED COMPOUNDS IN BIOLOGY

- ALTERNACY SYMMETRY - SECOND QUANTIZATION

1958 LAID THE FOUNDATIONS (TOGETHER WITH RUDOLF ZAHRADNIK) FOR THE PRAGUE SCHOOL OF THEORETICAL QUANTUM CHEMISTRY

1960 ESTABLISHED AND LED THE QUANTUM CHEMISTRY GROUP AT THE PHYSICAL CHEMISTRY INSTITUTE OF THE CAS

1962 - USED OLD IBM COMPUTERS FOR ELECTRONIC STRUCTURE CALCULATIONS

1962 - CORRESPONDING MEMBER OF THE CAS

1964-67 SCIENTIFIC VISITS TO TURKEY, HUNGARY, SOVIET UNION, U.S.A.

\section{THE METAMORPHOSIS}

1968 LEFT FOR THE USA, 6 MONTHS AFTER AUGUST 1968

1968-73 PROFESSOR AT YESHIVA UNIVERSITY, NEW YORK, U.S.A.

\section{SEMINAL SCIENTIFIC CONTRIBUTIONS}

1973-2002 PROFESSOR AT THE FREE UNIVERSITY BERLIN. FOUNDED AND LED WITH VLASTA BONAČIĆ-KOUTECKÝ A WORLD-CLASS RESEARCH GROUP ON THEORETICAL CLUSTER SCIENCE

- ELECTRONIC LEVEL STRUCTURE OF METAL CLUSTERS

- ATOMIC STRUCTURE AND GEOMETRY OF METAL CLUSTERS

- SPECTROSCOPY, DYNAMICS, REACTIVITY, PHOTOCHEMISTRY OF CLUSTERS (PIONEERING STUDIES WHICH GREATLY BENEFITTED FROM EARLY WORK ON SURFACE STATES AND CHEMISORPTION)

- GENERAL QUANTUM CHEMICAL METHODOLOGY

1990 HONORARY MEMBER OF THE CZECH LEARNED SOCIETY

1990-2002 MAJOR CONTRIBUTIONS TO SCIENCE POLICY.

ESTABLISHED THE GRANT AGENCY OF THE CZECH ACADEMY OF SCIENCES 
The early life and youth of Jaroslav (Tablet A) reflected on the development of an extremely brilliant person under the most difficult hardships of the mid-twentieth century.

After graduating from high school in 1941, he worked as a laboratory assistant in industrial research. This was not done out of free choice, but saved him from being transported to a forced labor camp in Nazi Germany, which occupied Czechoslovakia at that time. After the Second World War he completed three years of studies of physics at the Charles University in Prague. However, in 1948 he was thrown for six months into a labor camp of the communist regime, being wrongly accused for attempts to leave the country, then under communist control. He managed to obtain his RNDr degree only in 1951, starting to conduct his early important scientific research on polarographic kinetics. For this work, together with professor Rudolf Brdička, he was awarded his first scientific prize in 1954. At about this time he joined the Institute of Physical Chemistry of the Czechoslovak Academy of Sciences, conducting important studies on surface states, chemisorption and heterogeneous catalysis. These studies on infinite systems constituted a basis for his future work on metal clusters.

His exploration of quantum mechanical methods in the studies of surface phenomena led Jaroslav Koutecký to the realm of theoretical quantum molecular sciences (Tablet B). In 1958, together with Professor Rudolf Zaharadnik, he laid the foundations for the world-class Prague Theoretical School of Quantum Chemistry.

During the years 1958-1967 he established and led the quantum chemistry group at the Physical Chemistry Institute of the Czechoslovak Academy of Sciences. In 1962, when large-scale computer equipment was scarce all over the world, he used an old IBM computer in Prague for advanced electronic structure calculations. His important contributions to theoretical chemistry encompassed the exploration of the stability, electronic spectra and chemical reactivity of $\pi$ electron systems, the advancement of the Koutecký states involving low lying valence excitations, which are of importance for carotene-based compounds in biology, and the development of a conceptual framework for symmetry effects in second quantization. In 1962 he was elected as a corresponding member of the Czechoslovak Academy of Sciences and the world opened up for him with scientific visits to Turkey, Hungary, the Soviet Union and the USA.

During Jaroslav's visit to Turkey in 1964, our paths crossed for the first time at the International Istanbul Summer School in Modern Quantum Chemistry, which convened in Istanbul. I so well remember his important contributions and his impressive Istanbul lectures on excited states of $\pi$ electron systems, which established structure-electronic level structure-spectroscopic relations for large aromatic molecules. In comparing the calculated excitation energies with the experimental absorption spectra he used stick diagrams, so ubiquitous in his future work with Vlasta Bonačić-Koutecký on clusters. Another important Istanbul lecture by Jaroslav addressed the effects of charge transfer interactions in molecules with transannular interactions, e.g., paracyclophanes, which constitute covalently bound clusters. His work was of great inspiration for me.

The next developments in Jaroslav's life (Tablet C) reflected on his deep convictions regarding human values. Six months after the Russian tanks rolled into Prague, with the Soviet occupation, Jaroslav left Czechoslovakia. During these dark days in contemporary history, he was expelled from the Czechoslovak Academy of Sciences, a uniquely harsh step in that world! In 1990 he was restored and appointed as an Honorary Member of the Czechoslovak Academy.

In 1973 Jaroslav returned to Europe, accepting a Professorship at the Free University of Berlin (Tablet D). The Berlin days (1973-2000) marked his seminal scientific work in the area of cluster science. Together with his wife, Vlasta Bonačić-Koutecký, he founded and led a world-class research group in theoretical cluster science. This important work made central contributions to the electronic level structure, atomic structure and geometry of metal clusters. We are all profoundly influenced by his deep and exhaustive studies published in the Chemical Review, addressing clusters of all elements. His subsequent pioneering studies of spectroscopy, dynamics and reactivity of clusters had an audible impact on the development of the modern research area of analysis and control of chemistry and photochemistry of large finite systems. Concurrently, after the liberation of Czechoslovakia, Jaroslav made major contributions to science policy in his country.

Jaroslav was taken from us on August 20, 2005. He was a remarkable scientist, with strongest convictions about the norms and values of science, of society and of human endeavor. He always manifested outstanding scientific insight, deep perception, profound integrity and strongest convictions. His family, his scientific family and his friends will miss him.

Joshua Jortner,

School of Chemistry, Tel Aviv University,

Ramat Aviv, Tel Aviv 69511, Israel. 